the Permanent Committee of the Internationa] Zoological Congress, and honorary fellow of the Zoological Society and foreign member of the Linnean Society, which awarded him its Gold Medal in 1947. Caullery's 'Jubilé Scientifique' on his seventieth birthday in 1939 was the occasion of remarkable tributes to him and his work paid by many distinguished men of science. His contributions to zoology and general biology are remarkable for their positive and fundamental nature, their wide range and their stimulating character. He has made great contributions to parasitology in a variety of distinct groups of animals. It was he who discovered the Haplosporidia, a new order of Sporozoa. He worked out the life-cycles and relationships of parasites in many groups, particularly Crustacea, Turbellaria and Orthonectidæ. His studies have thrown much light on the biological relations of a parasite to its host.

Prof. L. C. Pauling, professor of chemistry in the California Institute of Technology, is distinguished for his researches on valency and on structural organic and inorganic chemistry. Through his profound knowledge of physics and mathematics he has been able to apply quantum mechanies to problems of chemical valency bonds. His comprehensive work is embodied in his book, "The Nature of the Chemical Bond" (1939), which is now recognized as a classic in chemistry. For this, and other cognate researches, Prof. Pauling was awarded the Davy Medal of the Royal Society in 1947.

\section{Pontifical Academy of Science : New Members}

THE following have been appointed members of the Pontifical Academy of Science: Prof. J. M. Albareda-Herrera, professor of geology and director of the Institute of Edaphology, Ecology and Plant Physiology, University of Madrid; Sir Edward Appleton, secretary of the Department of Scientific and Industrial Research, London; Prof. E. CruzCoke, professor of physiological and pathological chemistry, University of Santiago; Prof. A. De Castro, professor of clinical medicine, University of Madrid ; Prof. Edward A. Doisy, professor of biochemistry, St. Louis University School of Medicine ; Prof. Herbert S. Langfeld, Stuart professor of psychology and chairman of the Department of Psychology, Princeton University.

\section{Physiology at St. Andrews : Prof. P. T. Herring}

THE retirement of Prof. P. T. Herring from the Chandos ehair of physiology in the University of St. Andrews brings to a close a long term of office, for he has occupied the chair for forty years. Prof. Herring was educated in New Zealand and later at the University of Edinburgh, where he came under the influence of Sir Edward Sharpey-Schafer, with whom he later collaborated. His first researches, published in 1908, concerning the development and structure of the pituitary gland, quickly gained recognition and gave the histological background for many of the earlier investigations on the function of this body. The colloid bodies he described are still referred to as 'Herring's bodies', and illustrations of his original preparations demonstrating the vascular bed of the pituitary are to be found in current textbooks. Later, the structure and function of the thyroid claimed his interest, and again he was responsible for contributing much valuable knowledge. Prof. Herring went to St. Andrews in 1908 with a reputation as a lecturer of great distinction, and during his tenure of the Chandos chair he has systematically developed the Department of Physiology and the teaching courses in accordance with current physiological thought. He himself has invariably undertaken the greater part of the teaching in his Department, and there will be many at this time who will recall his clear and stimulating lectures. In addition to his other duties, Prof. Herring has taken a large and vital part in the administration of the University of St. Andrews. He acted as dean of the Faculty of Science during 1921-39 and served as an assessor of the Senatus on the University Court for four periods. His colleagues and the many students who have gained so much from his kindly interest and help will wish him long years of quiet and happiness in his retirement.

\section{Dr. A. E. Ritchie}

DR. A. E. RITCHIE, who has been appointed to the chair of physiology in the University of St. Andrews in succession to Prof. P. T. Herring, has had a wide training, having graduated M.A. and B.Sc. in mathematics, zoology and physiology at the University of Aberdeen, and later, in 1940, obtained the M.B., Ch.B. in the University of Edinburgh. In 1945 he was awarded the Gold Medal for his M.D. thesis on the electrical diagnosis of nerve injury. His postgraduate work began when he was holding a Carnegie Scholarship in the Physiology Department of the University of Edinburgh. In that Department he has stayed, combining varied teaching experience with original research. His most important contribution, both to physiology and medicine, has been to design a reliable and relatively simple and compact electronic appar. atus for the determination of strength-duration curves, thus converting a laboratory procedure into a practical clinical one. This apparatus is valuable in the diagnosis of nerve injury. Thus Dr. Ritchie's interests lie in the fields both of physiology and of clinical medicine. He has published a number of papers on muscle and nerve reactions both in health and disease, and has contributed an article on muscle reactions in the forthcoming "Encyclopædia of British Surgical Practice".

\section{Proposed Central Publication of Scientific Papers}

Mrs. Lucia MоноLy, of 127 Sloane Street, London, S.W.1, writes : "In describing American methods of auxiliary publication in Nature of June 5 (p. 896), Mr. Watson Davis speaks with authority on the practical value of certain organised measures adopted in the United States to a larger extent than in some other countries. If corresponding methods have not yet attained comparable popularity in Great Britain, it does not follow that the question of systematically using and organising photographic reproduction to assist science and learning has not been taken care of. Not only have suggestions for extensive uses been put forward on many occasions, but also a specific study has been made of the part photographic reproduction can play in relation to Prof. J. D. Bernal's project. With the Royal Society's Scientific Information Conference in sight, a formal statement setting out the merits of these methods for alternative and supplementary services was drafted and, upon Prof. Bernal's request, submitted to the appropriate quarter. This followed an outline of these methods and their potential uses for the publication and distribution of scientific papers, at a meeting on Apri 21, at the Society for Visiting Scientists. An earlier approach, also with specific reference to Prof. Bernal's project, was made at the Conference on the Publica- 
tion and Classification of Scientific Knowledge, held at Trinity College, Cambridge, on October 25, 1947.

"The use of documentary reproduction for auxiliary publication, and its eminent suitability as an aid to science and learning in general, were the subject of two articles in Nature $(157,29,38 ; 1946)$, where a new type of service was forecast to 'keep men of science currently informed of all the literature published on their respective subjects'. It was there, also, that the setting up of central agencies was suggested and interchange of services and close co-operation with bibliographical centres and scientific institutions was advocated. A memorandum to this effect was also submitted to Unesco (through the offices of its predecessor, the Conference of Allied Ministers of Education, 1945). In a paper read to the Royal Society Empire Scientific Conference, 1946 (Report, vol. 1, pp. 717-721), and another put before the Co-operation Committee of the Library Associa. tion in the same year, the setting up of a Central Office of Documentary Reproduction was recommended to act as a co-ordinating centre for Great Britain and the British Commonwealth and Empire; while a renewed appeal for the co-ordination of policy in Documentary Reproduction on a world scale was made to the Sixteenth Conference of the International Federation of Documentation in Paris, November 1946 (F.I.D. Communicationes, 13, Fasc. 4, 60; 1946). For the furtherance of these ideas, Mr. Watson Davis' letter has provided valuable evidence which should bring closer to realization some of the services for which the plans have been prepared in former years."

\section{British Commonwealth of Nations Scientific Liaison Offices}

THE British Commonwealth of Nations Scientific Liaison Offices (London) have been opened on the third floor of Africa House, Kingsway, W.C.2. This is one of the measures to facilitate co-operation in the civil aspects of science within the Commonwealth decided on by the British Commonwealth Scientific Official Conference held in London in 1946. For a number of years several of the Commonwealth countries have maintained scientific liaison offices in London, and these, together with the ones now being established, will have their headquarters in Africa House. Each of these offices will continue to operate as in the past, retaining complete independence of action; but the convenience of occupying adjacent premises will facilitate co-operation between them on matters of common interest. For ease of reference to the group of independent offices as a whole, the title given above has been chosen, with the abbrevia. tion B.C.S.O. (London) for common use. The offices taking part in the scheme are those of Australia, Canada, Central African Council, India, New Zealand, South Africa and the United Kingdom. Pakistan and the Commonwealth Agricultural Bureaux will be represented, and the Overseas Liaison Division of the U.K. Department of Scientific and Industrial Research will work in Africa House. In Washington the scientific liaison offices of the Commonwealth countries are associated under a similar scheme.

\section{British Seismological Observatories}

THE Stonyhurst College Observatory has now ceased to record earthquakes, as has also the Royal Observatory at Edinburgh. Mr. E. W. Pollard has moved from the Isle of Wight to Dorking, Surrey, and hopes to set up his seismograph at his new home. He has presented a seismograph with mass $40 \mathrm{lb}$. to the County Secondary Grammar School at Newport, Isle of Wight, where the instrument has been set up and is being standardized. It is hoped to install good time-keeping apparatus shortly.

\section{International Seismological Summary}

SnNCE the British Association meeting in September 1947, the United Nations Educational, Scientific and Cultural Organisation has given a substantial grantin-aid to the International Union of Geodesy and Geophysics for the International Seismological Summary (see Nature, April 17, p. 616). The staff of the I.S.S., consisting of Mr. J. S. Hughes and two assistants, have been at work at Kew for more than a year now, and the full issue for the year 1936 has been produced and partly distributed. In addition, much work has been done on the Summary for 1937, portions of this being in the hands of the printers. We are informed by Dr. Wang Ging-Hsi, of the Natural Sciences Section of Unesco, that the Organ. isation will assist similarly with another grant in the present year.

\section{Natural History Journals}

ONE by one som? of the journals whose light flickered and went out in 1939 are being revived. The latest is the Scottish Naturalist which now enters on its fifth stage under the joint editorship of Prof. V. C. Wynne-Edwards and Dr. J. W. Campbell. The first volume of the new series is mainly devoted to birds of Scotland. That country has also produced a new journal, Scottish Zoo and Wild Life; this has been inaugurated by the Zoological Society of Scot. land for the bənefit of its fellow's and all who are interested in animal life. Cordial wishes for their success are extended to both these journals while naturalists everywhere will also wish to congratulate the North-Western Naturalist on reaching its twentyfirst anniversary under the able editorship of $\mathrm{Mr}$. A. A. Dalliman.

\section{National Advisory Council for Education in Industry and Commerce}

THE following have been elected to serve on the Standing Committee of the National Advisory Council for Education in Industry and Commerce: Lieut.-General Sir Ronald Weeks (ehairman), Sir Samuel Gurney-Dixon (vice-chairman), Sir Graham Savage, Mr. E. L. Russell, Mr. A. Ballard, Dr. Percy Dunsheath, Prof. F. H. Garner, Prof. R. G. Batson, Sir Robert Wood, Dr. T. J. Drakeley, Dr. H. Schofield, Mr. J. Wilson, Dr. J. E. Myers, Sir Charles Tennyson, Sir Arthur Smout, Mr. G. S. Heaven, Sir Arthur Fleming, Mr. B. J. Ewing, Mr. G. H. Lowthian, Mr. W. T. Mainwaring, Mr. M. F. Titterington, M.P., Mr. E. G. Gooch, M.P., Dr. F. C. Toy, the Hon. Josiah Wedgwood, Captain A. M. Holbein. Sir Samuel Gurney-Dixon was also elected vice-chairman of the Council.

\section{Institution of Mining and Metallurgy: Awards}

THE Gold Medal of the Institution of Mining and Metallurgy, the highest distinction which the Council of the Institution has power to grant, has been awarded to Mr. G. Carleton Jones, resident director in South Africa of New Consolidated Gold Fields, Ltd., in recognition of his distinguished services to the gold mining industry of South Africa, and in particular to the development of the West Rand. Honorary membership of the Institution has been 